\title{
RANCANGAN PUZZLE GAME DELBELDES
}

\author{
Elisa Usada ${ }^{1}$, Feby Artwodini Muqtadiroh ${ }^{2}$ \\ ${ }^{1}$ Program Studi Diploma III Teknik Telekomunikasi, Purwokerto \\ ${ }^{2}$ Institut Teknologi Sepuluh Nopember, Surabaya \\ 1elisa@akatelsp.ac.id, ${ }^{2}$ feby@its-sby.edu
}

\begin{abstract}
ABSTRAK
Puzzle game merupakan genre game yang paling diminati, demikian juga dengan adventure game. Penelitian ini bertujuan membuat sebuah rancangan game dengan genre puzzle namun menyisipkan adventure di dalamnya. Metodologi yang digunakan adalah metodologi perancangan software berorientasi objek. Perangkat pemodelan yang digunakan adalah use case diagram, state diagrams dan class diagram. Perancangan menghasilkan delapan belas class diagram yang dapat dituangkan dalam bentuk kode bahasa pemrograman berorientasi objek.
\end{abstract}

Kata kunci : puzzle adventure game, delbeldes, game borobudur

\section{Pendahuluan}

Game adalah media yang berkembang pesat dalam dua dasawarsa terakhir. ${ }^{[2]}$ Puzzle game merupakan salah satu genre casual games yang paling diminati ${ }^{[3]}$, demikian juga adventure game. Penelitian ini bertujuan membuat rancangan desktop game dengan genre puzzle dan adventure. Game dalam penelitian ini selanjutnya dinamakan Game Delbeldes.

\section{Metodologi Penelitian}

Metode Perancangan yang digunakan adalah metode perancangan berorientasi objek. Proses perancangan berorientasi objek melibatkan perancangan kelas objek dan hubungan antara kelas-kelas tersebut. ${ }^{[4]}$ Alat perancangan yang digunakan adalah UML (Unified Modelling Language). UML adalah sekelompok notasi grafis yang membantu mendeskripsikan dan mendesain sistem yang dibangun secara berorientasi objek. ${ }^{[1]}$ Diagram UML ada 13 jenis diagram, penelitian ini menggunakan use case diagram, activity diagram, state chart dan class diagram.

\section{Hasil dan Pembahasan}

\subsection{Skenario Game}

Skenario game dimulai dari terjadinya sebuah gempa di wilayah Jawa Tengah yang menyebabkan bangunan Candi Borobudur rusak parah. Gempa mengakibatkan bongkahanbongkahan batu penyusun Candi Borobudur tercecer dimana-mana, bahkan memungkinkan bongkahan tersebut tertimbun tanah, di tepian atau di dasar sungai, berserakan di jalan setapak dan di sawah-sawah sekitar Candi Borobudur. Game ini bertujuan mengumpulkan bongkahan batu candi yang di yang tercecer untuk dibangun kembali.

Lingkungan game dibagi menjadi lingkungan sawah, sungai dan jalan setapak. Game dimulai dengan memberi pilihan kepada pemain, lingkungan mana yang akan dieksplorasi pertama kali. Game akan memunculkan pola puzzle yang harus dilengkapi oleh pemain. Pola puzzle ini dilengkapi dengan beberapa potongan sebagai inisiasi awal. Potongan-potongan puzzle yang digunakan untuk 
melengkapi puzzle adalah bongkahan batu yang harus dicari oleh pemain.

Bongkahan batu yang dicari oleh pemain tersebar di dalam lingkungan game yang sedang dieksplorasi pemain. Tempat terdapatnya bongkahan ditandai dengan tanda tertentu. Namun tidak semua bongkahan yang ada di lingkungan game dapat digunakan untuk melengkapi puzzle. Perbesaran objek bongkahan batu yang tersebar dilakukan dengan cara mengarahkan mouse pada icon yang menandai tempat bongkahan batu. Perbesaran dilakukan untuk melihat pola potongan batu sehingga dapat terlihat apakah pola potongan sesuai dengan pola potongan puzzle yang harus dilengkapi.

Puzzle dilengkapi dengan cara klik pada tanda bongkahan batu, lalu seret mouse ke arah pola potongan yang ingin dilengkapi. Pemain melengkapi puzzle dengan dibatasi waktu, sehingga setiap melakukan perbesaran objek yang tersebar di lingkungan game, pemain harus terus mengingat letak setiap bongkahan batu beserta bentuk polanya.

\subsubsection{Aturan Permainan}

Aturan permainan adalah sebagai berikut:

1. Permainan yang harus diselesaikan oleh pemain adalah melengkapi pola puzzle dengan bongkahan-bongkahan batu candi.

2. Permainan dibagi menjadi tiga level. Pemain harus menyelesaikan tiga stage dalam setiap level. Setiap stage memiliki lingkungan yang berbeda yaitu sawah, sungai dan jalan setapak. Setiap stage dalam setiap level memiliki batasan waktu permainan yang sama. Stage pada setiap level dapat diselesaikan secara acak oleh pemain.

3. Permainan dibatasi oleh waktu, waktu untuk setiap level berbeda, semakin tinggi level maka semakin singkat waktu yang diberikan kepada pemain. Jika hingga batas waktu yang ditentukan puzzle belum dapat diselesaikan, kesempatan bermain yang direpresentasikan dalam bentuk nyawa pemain akan berkurang.

4. Level satu memiliki waktu sepuluh menit permainan untuk masing-masing stage. Level dua memiliki waktu tujuh menit untuk masing-masing stage. Level tiga memiliki waktu empat menit untuk masingmasing stage.

5. Bongkahan batu yang tersebar diantaranya terdapat bongkahan batu kutukan yang jika terambil oleh pemain akan mengakibatkan potongan-potongan puzzle yang berhasil diselesaikan menjadi hangus separuhnya.

\subsubsection{Skor Permainan}

Skor ditentukan berdasarkan banyaknya waktu yang diperlukan pemain untuk menyelesaikan puzzle. 
Tabel 1. Skor Game

\begin{tabular}{|c|c|c|}
\hline Level & $\begin{array}{c}\text { Lama } \\
\text { Penyelesaian } \\
\text { Permainan }\end{array}$ & Skor \\
\hline \multirow[t]{2}{*}{1} & $\mathrm{t} \leq 5$ menit & $\begin{array}{l}\text { Skor } 100 \quad \text { dengan } \\
\text { tambahan } \\
\text { permainan untuk stage } \\
\text { berikutnya sebesar } 5 \\
\text { menit }\end{array}$ \\
\hline & $\begin{array}{l}5<\mathrm{t} \leq 10 \\
\text { menit }\end{array}$ & $\begin{array}{lr}\begin{array}{l}\text { Skor } 100 \\
\text { tambahan } \\
\text { permainan }\end{array} & \text { waktu } \\
\end{array}$ \\
\hline \multirow[t]{2}{*}{2} & $\mathrm{t} \leq 4$ menit & $\begin{array}{l}\text { Skor } 100 \quad \text { dengan } \\
\text { tambahan } \\
\text { permainan } \\
\text { berikutnya } \\
\text { menit }\end{array}$ \\
\hline & $\begin{array}{l}4<\mathrm{t} \leq 7 \\
\text { menit }\end{array}$ & $\begin{array}{lr}\begin{array}{l}\text { Skor } 100 \\
\text { tambahan } \\
\text { permainan }\end{array} & \text { waktu } \\
\end{array}$ \\
\hline 3 & $\mathrm{t} \leq 2$ menit & $\begin{array}{l}\text { Skor } 100 \quad \text { dengan } \\
\text { tambahan } \\
\text { permainan } \\
\text { berikutnya } \\
\text { menit }\end{array}$ \\
\hline 4 & $\begin{array}{l}2<\mathrm{t} \leq 4 \\
\text { menit }\end{array}$ & $\begin{array}{lr}\text { Skor } 100 & \text { tanpa } \\
\text { tambahan } & \text { waktu } \\
\text { permainan } & \end{array}$ \\
\hline
\end{tabular}

Bonus berupa terpasangnya beberapa potong puzzle secara otomatis sehingga mengurangi pekerjaan pemain. Bonus diberikan apabila pemain dapat menjawab pertanyaan yang tersembunyi di lingkungan game dengan benar. Pertanyaan merupakan pertanyaan acak di bidang matematika dan sejarah. Pertanyaan bonus dalam game ini tidak menjadi fokus utama penelitian. Contoh pertanyaan bonus adalah :

1. Untuk membuat Candi Borobudur diperlukan 1580 buah bongkahan batu, berat 1 bongkahan batu adalah sebesar 0,3 $\mathrm{kg}$. Berapa kg total dari berat volume Candi Borobudur?

2. Seorang siswa dengan tinggi $145 \mathrm{~cm}$ berdiri pada jarak 10 meter dari Candi Borobudur. Ia memandang ke arah puncak Candi dengan sudut elevasi 40 derajat. Berapakah tinggi sebenarnya Candi Borobudur itu?

3. Pada Abad berapa Candi Borobudur dibangun?

\subsection{Diagram UML}

Tahap konseptualisasi dilakukan dengan pembuatan use case diagram. Use case diagram menggambarkan bagaimana game Delbeldes akan digunakan oleh pengguna. Fungsi-fungsi yang harus ada di dalam game tergambar di dalam use case diagram.

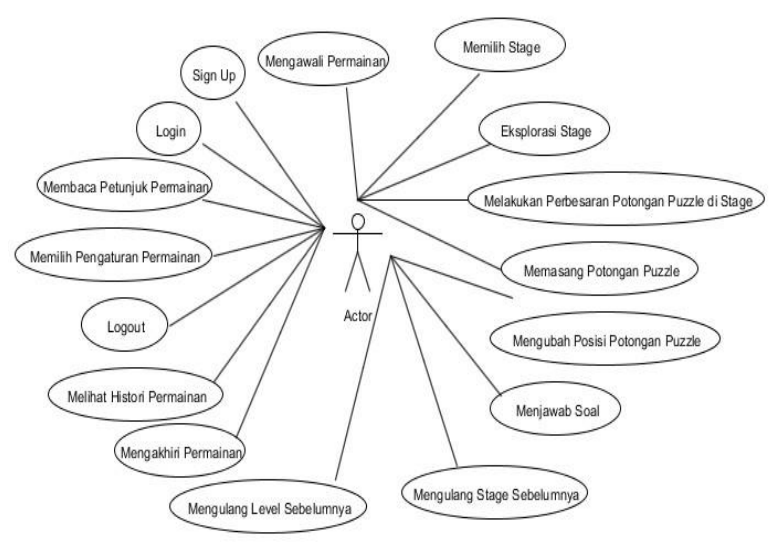

Gambar 1 Use Case Diagram Game Delbeldes 
Tingkah laku dan kejadian-kejadian di dalam sistem diidentifikasi dengan menggunakan sekuen diagram.

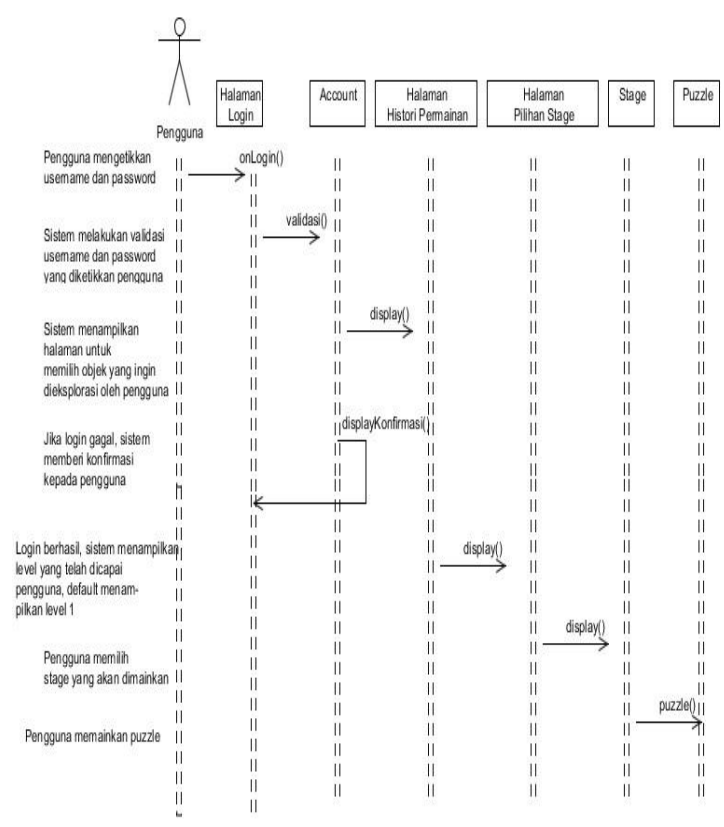

Gambar 2 Diagram Sekuen Game Delbeldes

Selanjutnya dari diagram sekuen dapat dikembangkan class diagram.

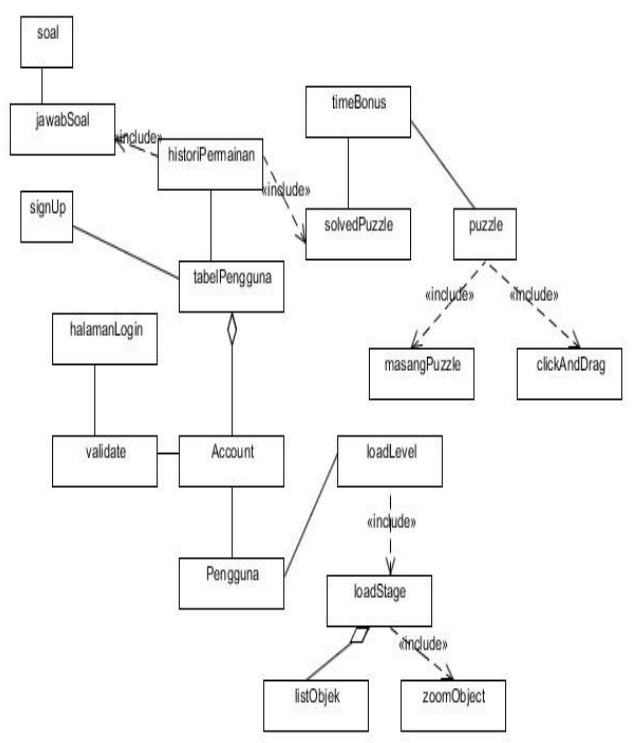

Gambar 3 Class Diagram Game Delbeldes

\subsection{Rancangan Hierarki Menu Game}

Rancangan hierarki menu game delbeldes dapat dilihat pada diagram blok berikut ini.

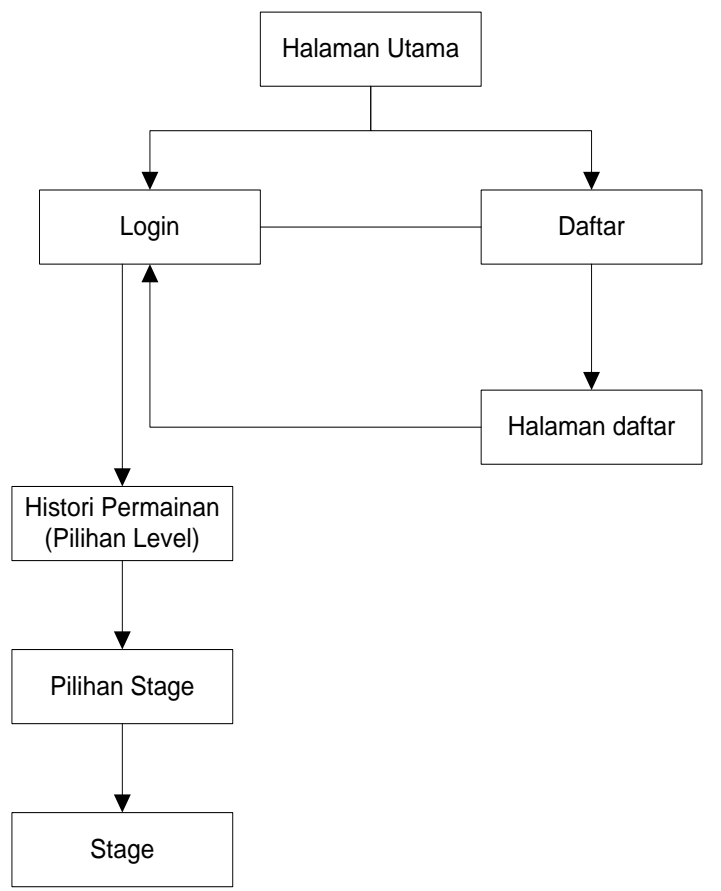

Gambar 4 Hirarki Menu Game Delbeldes

\subsection{Rancangan Antar Muka Game}

Rancangan antarmuka dapat dilihat pada Gambar berikut.

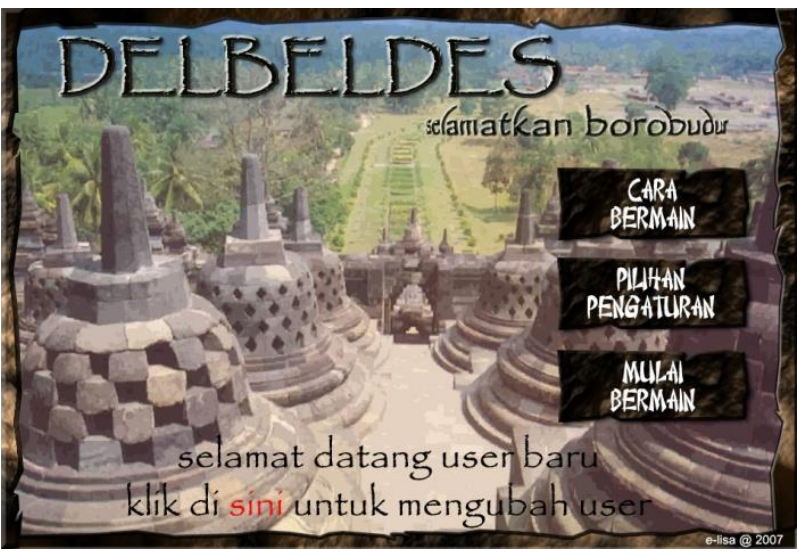

Gambar 5. Rancangan tampilan antar muka game Delbeldes 


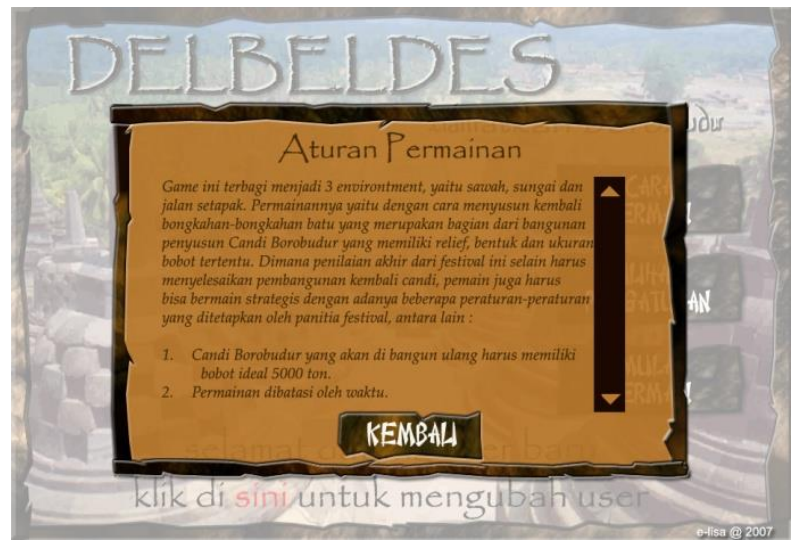

Gambar 6. Rancangan tampilan antar muka halaman petunjuk game Delbeldes

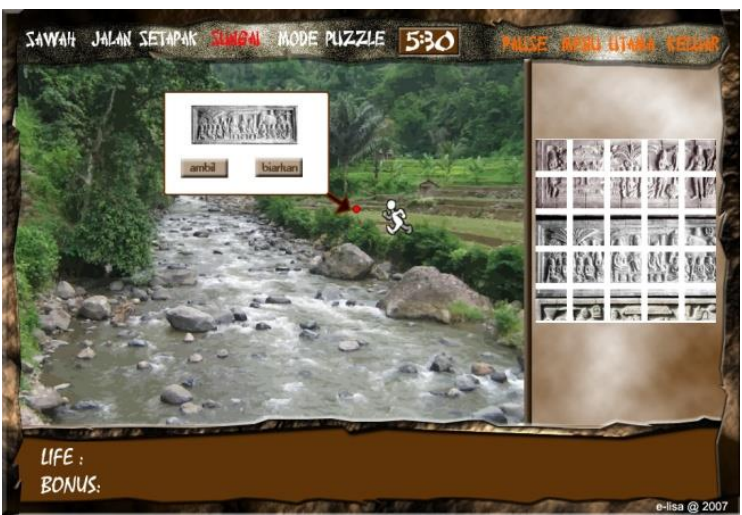

Gambar 7. Rancangan tampilan antar muka halaman inti permainan

\section{Penutup}

Proses perancangan menghasilkan 18 class diagram yang nantinya akan dibuat kodenya dalam bahasa pemrograman berorientasi objek.

\section{Daftar Pustaka:}

[1] Fowler, Martin. 2004. UML Distilled: A Brief guide to The Standard Object Modelling Language, $3^{r d}$ Edition. USA. Pearson Education, Inc.

[2] Henry, Samuel. 2010. Cerdas dengan Game: Panduan Praktis bagi Orang Tua dalam Mendampingi Anak Bermain Game. Jakarta. PT Gramedia.

[3] Ray, Sheri G. 2004. Gender Inclusive Game Design: Expanding The Market. USA. Charles River Media, Inc.

[4] Sommerville, Ian. 2003. Software Engineering (Rekayasa Perangkat Lunak): Edisi 6, Jilid 1. Jakarta. Penerbit Erlangga. 